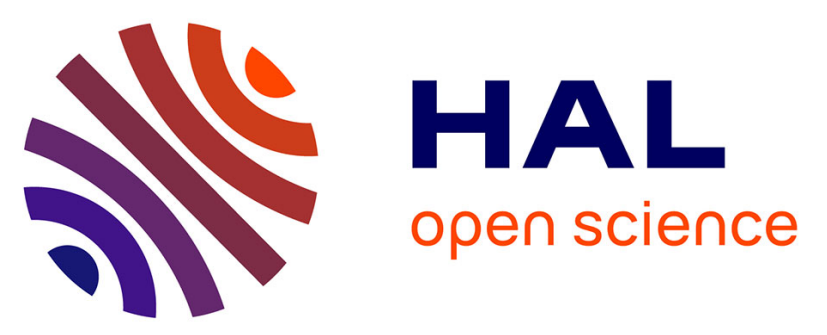

\title{
Use of continuous measurements of dissolved organic matter fluorescence in groundwater to characterize fast infiltration through an unstable fractured hillslope (Valabres rockfall, French Alps)
}

Jean-Baptiste Charlier, Catherine Bertrand, Stéphane Binet, Jacques Mudry, Nicolas Bouillier

\section{To cite this version:}

Jean-Baptiste Charlier, Catherine Bertrand, Stéphane Binet, Jacques Mudry, Nicolas Bouillier. Use of continuous measurements of dissolved organic matter fluorescence in groundwater to characterize fast infiltration through an unstable fractured hillslope (Valabres rockfall, French Alps). Hydrogeology Journal, 2010, 18 (8), pp.1963-1969. 10.1007/s10040-010-0670-5 . insu-00536892

\section{HAL Id: insu-00536892 \\ https://hal-insu.archives-ouvertes.fr/insu-00536892}

Submitted on 9 Feb 2011

HAL is a multi-disciplinary open access archive for the deposit and dissemination of scientific research documents, whether they are published or not. The documents may come from teaching and research institutions in France or abroad, or from public or private research centers.
L'archive ouverte pluridisciplinaire HAL, est destinée au dépôt et à la diffusion de documents scientifiques de niveau recherche, publiés ou non, émanant des établissements d'enseignement et de recherche français ou étrangers, des laboratoires publics ou privés. 


\title{
Use of continuous measurements of dissolved organic matter fluorescence in groundwater to characterize fast infiltration through an unstable fractured hillslope (Valabres rockfall, French Alps)
}

Jean-Baptiste Charlier ${ }^{1}$, Catherine Bertrand ${ }^{1}$, Stéphane Binet ${ }^{1,2}$, Jacques Mudry ${ }^{1}$ and Nicolas Bouillier ${ }^{1}$

(1) Chrono-Environment - UMR UFC/CNRS 6249, University of Franche-Comté, 16 route de Gray, F-25030 Besançon, France

(2) Institut des Sciences de la Terre d'Orléans - UMR 6113, Université d'Orléans, CNRS/INSU, Université François Rabelais - Tours, 1A, rue de la Férollerie, 45071 Orléans, France

Jean-Baptiste Charlier : jb.charlier@gmail.com

\begin{abstract}
Continuous measurements of natural fluorescence of dissolved organic matter (DOM) in groundwater have been used to characterize infiltration through an unstable fractured hillslope at the event time scale. Within the gneissic Valabres rockfall area in the southern French Alps, two sites, in the unstable massif and in the collapse area, were continuously monitored for electrical conductivity and for DOM natural fluorescence using a field fluorometer, and analyzed weekly for hydrochemical data. Two main results were found. From a methodological point of view, DOM natural fluorescence was a relevant tracer of fast infiltration in fissured media, knowing that continuous measurements improved the study of infiltration processes at the event time scale. From a hydrogeological point of view, the unstable fractured massif showed delayed dilution phenomena and the collapse areas showed fast and slow infiltration by piston-type flows via more or less open fractures. Consequently, from this conceptual model one may suppose that, unlike the collapse zones, the fractured hillslope threatening the valley is not submitted to strong pore-water pressure variations.
\end{abstract}

Keywords Dissolved organic matter - Groundwater flow - Unstable slope - Fractured rocks France

\section{Introduction}

Water infiltration is a key process in landslide triggering, and hydrogeochemical studies can give tools to characterize physical properties of rock slopes (Bogaard et al. 2007). In a fracture network within low porosity rock, a small infiltrated water volume can create large pressure. In this setting, fast infiltrations need to be well characterized in order to determine slope stability accurately.

Because infiltrated water contains large amounts of organic soil substances, the natural fluorescence (NF) of dissolved organic matter (DOM) and total organic carbon (TOC) are good tracers to discriminate water origin and flow paths in hydrosystems (e.g. Batiot et al. 2003; Carstea et al. 2009; Pronk et al. 2009). For TOC, a non-conservative tracer, mineralization occurs at the scale of a few weeks; laboratory experiments showed TOC has an exponential decay with time (Batiot 2002), meaning that the higher the TOC content, the faster the transit time in the system. TOC is thus adapted to study transfer time in hydrosystems at the event time scale. 
However, the measurement of TOC is technically difficult due to continuous mineralization in sampling bottles and to the difficult automation of such devices in the field. To overcome these drawbacks, one may use a field fluorometer, developed for artificial dye tracers by Schnegg (2003), which gives continuous measurements of water NF. Moreover, knowing that Cumberland and Baker (2007) showed DOM fluorescence and TOC are linearly correlated in freshwater, it is hypothesized that continuous NF measurements could be used as a fine infiltration tracer.

This article aims to characterize infiltration flows through an unstable basement massif. The original contribution of this work was to use continuous measurements of DOM NF in groundwater to monitor infiltration processes at the event time scale. The experimental site is the Valabres unstable hillslope in the southern French Alps. Two sites were monitored weekly for hydrochemical status and continuously for NF using a field fluorometer. The first site was a gallery draining the unsaturated zone of a fractured aquifer in the unstable massif, and the second was a spring draining a perched aquifer located in a highly fractured collapse zone. On the basis of contrasting results for these sites, a conceptual model is presented of infiltration flows at the event time scale.

\section{Study area and sampling site Study site}

The Valabres hillslope is located in the Tinée valley in the southern Alps (Fig. 1a and b). The relief is marked by deep valleys with steep slopes, and the land cover is mainly composed of scattered shrubs and bare rock outcrops. In this area, the geographical relation between spring location and geology defines three main aquifer types (Fig. 1b): (1) a shallow aquifer in the colluvium (glacial deposits and screes), (2) an aquifer in the sedimentary rocks of Jurassic and Triassic ages, and (3) an aquifer in the gneissic rocks, whose springs are located near fractures or faults. The hillslope deformation is characterized by a continuous collapse area of about $2 \mathrm{~km}^{2}$ (Fig. 1 $1 \mathrm{~b}$ ) showing a double ridge oriented north-south that extends $2 \mathrm{~km}$ in the massif and bounded by counter-slopes. A decompressed area with open fractures lies between a vertical tectonic fracture towards the north-west and a fracture dipping about $45^{\circ}$ towards the south-east. This collapsed area is bounded by undisturbed fractured rock forming stiff, currently unstable cliffs above the valley.

If one focuses on gneissic formations (with quartz, mica, plagioclase, K-feldspar, and amphibole), where main slope instabilities occur, most of springs are located at the middle of the slope, downstream of collapse zones (Fig. 1b). In the Valabres sector, the Tinée River crosses the regional geological structures. The bottom of the major trench zone is drained in the south-east by one of the most important springs of the valley, the Luicetta spring (Fig $\underline{1 \mathrm{c}}$ ).

The presence of a gallery, which enables performing investigations inside the rock mass, has served to monitor flows through the unstable massif. A sampling site was equipped in the gallery, and was coupled with the monitoring of the Luicetta spring, which drains the collapse area. These two sites in different geomorphological contexts were monitored physically and chemically. They are presented herein:

- Gallery. Flows from an undisturbed fracture in the gallery were collected to record the hydrological response of the unsaturated zone in the unstable fractured massif. The gallery has a geometry of $2.5 \mathrm{~m}$ width and of $2.3 \mathrm{~m}$ height, and is located under $100 \mathrm{~m}$ of overburden gneiss at the sampling site. According to Binet et al. (2007), the estimated infiltration transit velocity is between $1.10^{-5}$ and $1.10^{-4} \mathrm{~m} / \mathrm{s}$ (response time of $10-20$ days). 
- Spring. Flows from the Luicetta stream at $750 \mathrm{~m}$ above sea level (ASL), downstream from the Luicetta spring (900 m ASL), are representative of flows in a shallow collapsed zone. The spring drains the decompressed area at the convergence of the main fractures (Fig. 2c), which is the boundary between a collapsed zone and the fractured gneiss. The catchment has an estimated area of $10 \mathrm{ha}(+/-1 \mathrm{ha})$ and the spring has a minimum yield of $5 \mathrm{l} / \mathrm{s}$. According to Binet et al. (2007), the estimated infiltration transit velocity ranges between $2.10^{-2}$ and $8.10^{-}$ ${ }^{3} \mathrm{~m} / \mathrm{s}$ (response time of $1-4$ days).

\section{Method}

Measurements were conducted from 28 October 2007 to 04 April 2008, that is, 160 days of monitoring.

\section{Physical measurements}

Daily rainfall intensity is an arithmetic mean of the time series of the weather stations of Rimplas and Saint-Etienne de Tinée (METEO France 2009), located $17 \mathrm{~km}$ to the south and $25 \mathrm{~km}$ to the north, respectively. Electrical conductivity (EC) and temperature measurements were carried out every 15 min using automatic field equipment (OTT, Orpheus, Aix-enProvence, France).

DOM natural fluorescence (NF) was measured using a flow-through field fluorometer, GGUN-FL30 (Albillia, Neuchâtel, Switzerland), initially designed for tracer tests to measure dye tracer concentrations in the field (Schnegg 2002, 2003). The field fluorometer is equipped with four optical components selected according to the absorption-emission spectra of the chosen artificial dye. Each component includes a light source (light emitting diode LED) exciting the fluorescence of the dye, and a photo-detector which yields an electric voltage of amplitude proportional to the fluorescence. The measured fluorescence by the photo-detector is filtered by an optical filter. Dye concentrations (in ppb) are determined by calibration with solutions of the dye at various concentrations. In this study, for DOM NF measurement, a $370 \mathrm{~nm}$ UV LED (suited for Tinopal artificial dye) was used for excitation, and the fluorescence was measured between 440 and $540 \mathrm{~nm}$. The calibration of the field fluorometer was carried out using Tinopal at 10,100, and 1,000 ppb. The detection limit for this tracer ranged between 0.14 and $0.2 \mathrm{ppb}$, and the error on the measurement range was estimated to be $8 \%$ (Schnegg 2002). Measurements were scheduled every $15 \mathrm{~min}$. The light source of Tinopal was used because its excitation/emission wavelengths are in the range of organic matter fluorescence at high intensities: excitation between 200 and 400, and emission between 300 and 500 (i.e. Baker 2001; Katsuyama and Ohte 2002; Blondel 2008; Carstea et al. 2009). In order to calibrate this probe, Savoy (2007) has shown that a strong linear relationship between TOC and DOM NF (using a GGUN field fluorometer), exists in karstic systems. Moreover, Cumberland and Baker (2007) showed that DOM fluorescence (using a laboratory spectrofluorometer) and TOC are linearly correlated in freshwater. From these last results, in various environments, it is hypothesised that NF was a consistent signal of DOM in surface and groundwaters in the presented gneiss formations.

\section{Chemical measurements}

Chemical measurements were carried out using an automatic sampler (Teledyne ISCO, Lincoln, NE) comprising 24 bottles previously rinsed with distilled water. Automatic samples were collected every 3 months (15 October 2007, 22 January 2008, and 11 March 2008). At 
these dates, these samples were completed by manual samplings to analyze $\mathrm{HCO}_{3}{ }^{-}$and to calculate the ionic balances, which were better than $8 \%$, validating water analysis carried out by automatic samplers. Major ions were analyzed in the hydrogeological laboratory of Chrono-Environment (University of Franche-Comté, Besançon, France). For automatic samples, $\mathrm{HCO}_{3}{ }^{-}$was calculated in order to obtain a null ionic balance.

Results

Analysis of hydrogeological time series

The cumulative rainfall depth, $P$, for the whole monitoring period, was $374.4 \mathrm{~mm}$. As shown in Fig. 2, this period was characterized by two main events: (1) event 1 with a $P$ of $105 \mathrm{~mm}$ over the 5 days associated with 22 November 2007, for which there was a maximum rainfall intensity, Px, of $55 \mathrm{~mm} /$ day; (2) event 2 with a $P$ of $131 \mathrm{~mm}$ over the 7 days associated with 11 January 2008, for which there was a Px of $62 \mathrm{~mm} /$ day.

The time series of EC in Fig. 2 showed opposite responses to rainfall events in the gallery and the spring sites. In the gallery, EC values were globally high, ranging from 391 to $429 \mu \mathrm{S} / \mathrm{cm}$. The signal was stable, and after rainfall event 2 , there was a slight decrease of $38 \mu \mathrm{S} / \mathrm{cm}$ attributed to a response time of 14 days and a transit time of $8.10^{-5} \mathrm{~m} / \mathrm{s}$ in the unsaturated zone of the massif. After that decrease, EC reached a stabilized plateau of about $404 \mu \mathrm{S} / \mathrm{cm}$ but never rose to the initial signal.

At the spring, the baseline of the EC signal in Fig. 2 ranged from 160 to $180 \mu \mathrm{S} / \mathrm{cm}$, meaning that the residence time was lower than that of the gallery. One day after each rainfall event a drop was observed, followed by a recovery. For events 1 and 2, the decreases in EC were 18 and $46 \mu \mathrm{S} / \mathrm{cm}$, respectively. After both events, the recovery of the EC signal formed a slight dome (10 days after rainfall peak) of more mineralized water; the maximum EC dome was higher than in the pre-event conditions.

As for EC, the NF time series plotted in Fig. 2 showed opposite variations for the two sites. For the gallery, there was a quasi-null NF signal (0-0.2 ppb). At the spring, there was a baseline between 0.25 and $0.5 \mathrm{ppb}$ and peaks of NF reaching 8.5 and $12.0 \mathrm{ppb}$ after rainfall events 1 and 2, respectively. The response time was 1 day.

Analysis of hydrochemical time series

The results of hydrochemical analysis are synthesized in Table 1 . The two main observations were that (1) the highest concentrations were for $\mathrm{HCO}_{3}{ }^{-}, \mathrm{Ca}^{2+}$, and $\mathrm{SO}_{4}{ }^{2-}$, which were thus plotted in Fig. 2 and (2) as expected by the EC analysis in section Analysis of hydrogeological time series, concentrations in the gallery were 2- to 4-fold higher than for the spring. First, for the gallery, variations of $\mathrm{Ca}^{2+}, \mathrm{SO}_{4}{ }^{2-}$, and $\mathrm{HCO}_{3}{ }^{-}$were similar. Before event $2, \mathrm{Ca}^{2+}$ progressively rose from 55.0 to $72.5 \mathrm{mg} / 1, \mathrm{SO}_{4}{ }^{2-}$ from 70.0 to $74.5 \mathrm{mg} / \mathrm{l}$, and $\mathrm{HCO}_{3}{ }^{-}$from 94.0 to $147.2 \mathrm{mg} / \mathrm{l}$ followed after this event by a decrease of $15.5,8.6$, and $40.5 \mathrm{mg} / \mathrm{l}$, respectively. This pattern showed there was durable dilution of groundwater flows, as observed for the EC signal. Second, for the spring, $\mathrm{Ca}^{2+}$ and $\mathrm{HCO}_{3}{ }^{-}$variations were different from the variation of $\mathrm{SO}_{4}{ }^{2-}$. $\mathrm{Ca}^{2+}$ and $\mathrm{HCO}_{3}{ }^{-}$showed a rise of $6.5 \mathrm{mg} / \mathrm{l}$ from 21.5 to $28.0 \mathrm{mg} / \mathrm{l}$, and of $22.3 \mathrm{mg} / \mathrm{l}$ from 51.1 to $73.4 \mathrm{mg} / \mathrm{l}$, respectively, which was related to the EC dome 10 days after rainfall peak, whereas $\mathrm{SO}_{4}{ }^{2-}$ was very stable with a mean value of $18.5+/-$ $0.5 \mathrm{mg} / \mathrm{l}$.

\section{Discussion on fast and diffuse infiltrations}


The analysis of EC and NF fluctuations, shown in Fig. $\underline{2}$, revealed the dynamics differed for the two sites: a buffered response to rainfall (flat chemograph) in the gallery and a reaction with high intensity for the spring. First, for the gallery, the durable dilution of EC by event rainwater means that the system is highly inertial, due for example to a low permeability. The quasi-null NF signal showed that a pluri-week transit enabled mineralization of all organic substances in water. These observations showed that infiltration flows were diffuse.

Second, for the spring, EC and NF baselines indicated a shorter residence time than in the gallery, with higher NF and lower EC (i.e. lower mineralization) at the spring. To better characterize infiltration processes, NF vs. EC was plotted in Fig. $\underline{3}$. A clockwise hysteresis loop for each rainfall event was observed, shown by arrows. These hysteresis loops reflected differences in water-transit velocity. Three phases can be distinguished: (phase I) a decrease of EC (arrival of low mineralized water) without any change in DOM concentration; (phase II) an enrichment in organic substances (DOM peak) of less mineralized water, with a response time inferior to 1 day; (phase III) a higher increase of mineralization than the preevent water, and a decrease of DOM concentration, with a response time of 10 days, ending the hysteresis. These phases are coherent with the three following infiltration processes: (1) the occurrence of non-infiltrated event water (neither highly mineralized nor enriched with soil organic matter) by surface runoff, (2) the occurrence of infiltrated water by fast piston flows (not mineralized yet but enriched with soil organic matter), and (3) the occurrence of infiltrated water with a longer transit time allowing its mineralization (more mineralized but less enriched in soil organic matter).

The results are summarized in an infiltration model of the Valabres unstable rocks. Presented in Fig. 4, this model differentiates infiltration flows through the unsaturated zone of the deep aquifer localized in the unstable fractured massif, as well as in the perched aquifer localized in the weathered collapsed area. First, in the unsaturated zone of the unstable fractured medium (gallery), the durable decrease of chemographs and EC signal show mixing and dilution processes, as well as low storage. The small fluctuations of these signals also show a buffering effect of the massif characterized by low velocities of about $8.10^{-5} \mathrm{~m} / \mathrm{s}$ as stated by Binet et al. (2007) for the same site. Second, in the perched aquifer of the collapsed area (spring), three types of organized flows were distinguished: (1) a fast transit of surface runoff upstream from the Luicetta outlet (response time $<24 \mathrm{~h}$ ), (2) a fast transit via fast piston effect of water infiltrated in permeable fractures (transit velocity of about $10^{-2} \mathrm{~m} / \mathrm{s}$ ) with low water storativity, and (3) a 10-fold slower transit of water enriched in $\mathrm{Ca}^{2+}$ in less permeable media with higher storativity.

To study flows in fractured media, the main advantage of using continuous NF measurements is to expand the accuracy of EC when very recent seepage water is observed (about 1 week). In one case, EC signal at the outlet of an unstable rock is the result of two features for infiltrated water: its initial mineralization (rainwater), and its mineralization occurring during the transit time, with possibilities of water-rock interactions. In the other case, NF signal is the result of infiltration through the soil (enrichment of DOM) and is limited in time, because the mineralization of organic substances generates a rapid decrease of NF concentration (Batiot 2002). Thus, NF may be an irreplaceable supplement of EC because NF is a relevant tracer of fast infiltration, whereas EC is an integrating tracer of several concomitant processes as fast infiltration, or not, and residence time. This method serves well to discriminate flowpaths and appears to be widely adapted for fractured and karstic media. 
The infiltration model developed using a hydrochemical approach may serve to better understand repartitions and variations of pore-water pressures in unstable hillslopes. In fact, due to the contrasted infiltration processes in the various fracture networks highlighted in the model, one may suppose that pore-water pressures, which increase during the infiltration events, are dissipated by the collapsed zone and that the fractured hillslope threatening the valley is not submitted to strong pore-water pressure variations. This study calls for further investigations in order to improve hydromechanical models developed for unstable hillslopes, including the heterogeneity of hydrogeological responses highlighted in such a context.

\section{Conclusion}

The aim of this study was to use continuous measurements of natural fluorescence (NF) of DOM in groundwater to characterize infiltration at two sites of an unstable hillslope: a fractured medium and a collapsed zone. The results showed first that, from a methodological point of view, a continuous NF signal is a relevant tracer of fast infiltration that improves the study of flow processes at the event time scale. Second, from a hydrogeological point of view, the unstable fractured massif showed delayed dilution phenomena and the collapse areas showed fast and slow infiltration with piston flow types via more or less open fractures. Finally, the infiltration model designed through this hydrochemical approach gives tools to better characterize physical properties in an unstable hillslope.

Acknowledgements This research was financed by INERIS (Institut National de l'Environnement Industriel et des Risques) and the French Ministry of Ecology and Sustainable Development, through STABROCK "Impact of climate changes on the stability of rock slopes: observation, experimentation and modeling". Many thanks to Bruno Regent for the field work.

\section{References}

Baker A (2001) Fluorescence excitation-emission matrix characterization of some sewage-impacted rivers. Environ Sci Technol 35(5):948-953

Batiot C (2002) Étude expérimentale du cycle du carbone en régions karstiques [Experimental study of the carbon cycle in karst areas]. PhD Thesis, University of Avignon, France

Batiot C, Liñán C, Andreo B, Emblanch C, Carrasco F, Blavoux B (2003) Use of total organic carbon (TOC) as tracer of diffuse infiltration in a dolomitic karstic system: the Nerja Cave (Andalusia, southern Spain). Geophys Res Lett 30(22):2179.

doi:10.1029/2003GL018546

Binet S, Guglielmi Y, Bertrand C, Mudry J (2007) Unstable rock slope hydrogeology: insights from the large-scale study of the western Argentera-Mercantour hillslopes (south-eastern France). Bull Soc Géol Fr 178:159-168

Blondel T (2008) Traçage spatial et temporel des eaux souterraines dans les hydrosystèmes karstiques par les matières organiques dissoutes [Spatial and temporal tracing of groundwater in karstic hydrosystems using dissolved organic matter]. PhD Thesis, University of Avignon, France 
Bogaard T, Guglielmi Y, Marc V, Emblanch C, Bertrand C, Mudry J (2007) Hydrogeochemistry in landslide research: a review. Bull Soc Géol Fr 178: 113-126

Carstea EM, Baker A, Pavelescu G, Boomer I (2009) Continuous fluorescence assessment of organic matter variability on the Bournbrook River, Birmingham, UK. Hydrol Process 23:1937-1946

Cumberland SA, Baker A (2007) The freshwater dissolved organic matter fluorescence-total organic carbon relationship. Hydrol Process 21:2093-2099

Katsuyama M, Ohte N (2002) Determining the sources of stormflow from the fluorescence properties of dissolved organic carbon in a forested headwater catchment. J Hydrol 268:192-202

METEO France (2009) Rainfall data, 2007-2008. METEO France, Nice, France Pronk M, Goldscheider N, Zopfi J , Zwahlen F (2009) Percolation and particle transport in the unsaturated zone of a karst aquifer. Ground Water 47(3):361-369

Savoy $L$ (2007) Use of natural and artificial reactive tracers to investigate the transfer of solutes in karst systems, PhD thesis, University of Neuchâtel, Switzerland

Schnegg P-A (2002) An inexpensive field fluorometer for hydrogeological tracer tests with three tracers and turbidity measurement. XXXII IAH and ALHSUD Congress Groundwater and Human Development. Mar del Plata, Argentina, October 2002, Balkema, Rotterdam, The Netherlands, pp 1484-1488

Schnegg P-A (2003) A new field fluorometer for multi-tracer tests and turbidity measurement applied to hydrogeological problems. Proceedings of the Eight International Congress of the Brazilian Geophysical Society, Rio de Janeiro, September 2003, BGS, Rio de J aneiro

\section{Figures and Tables}



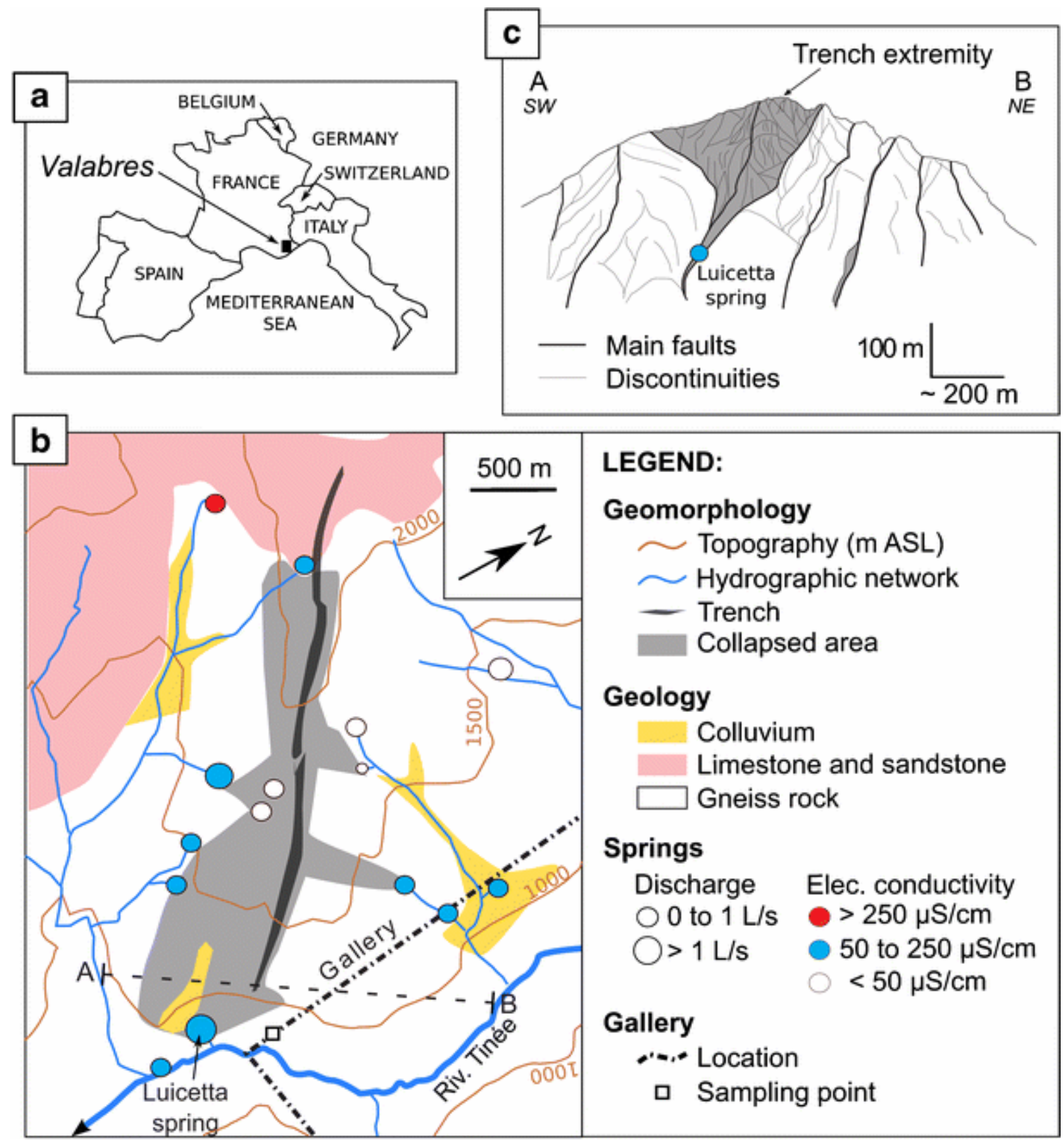

Fig. 1 a Location of the Valabres hillslope in the southern French Alps. b Hydrogeological map of the study site indicating the location of the gallery and the Luicetta spring. c Deep cross-section A-B showing the geomorphology of the Valabres hillslope 

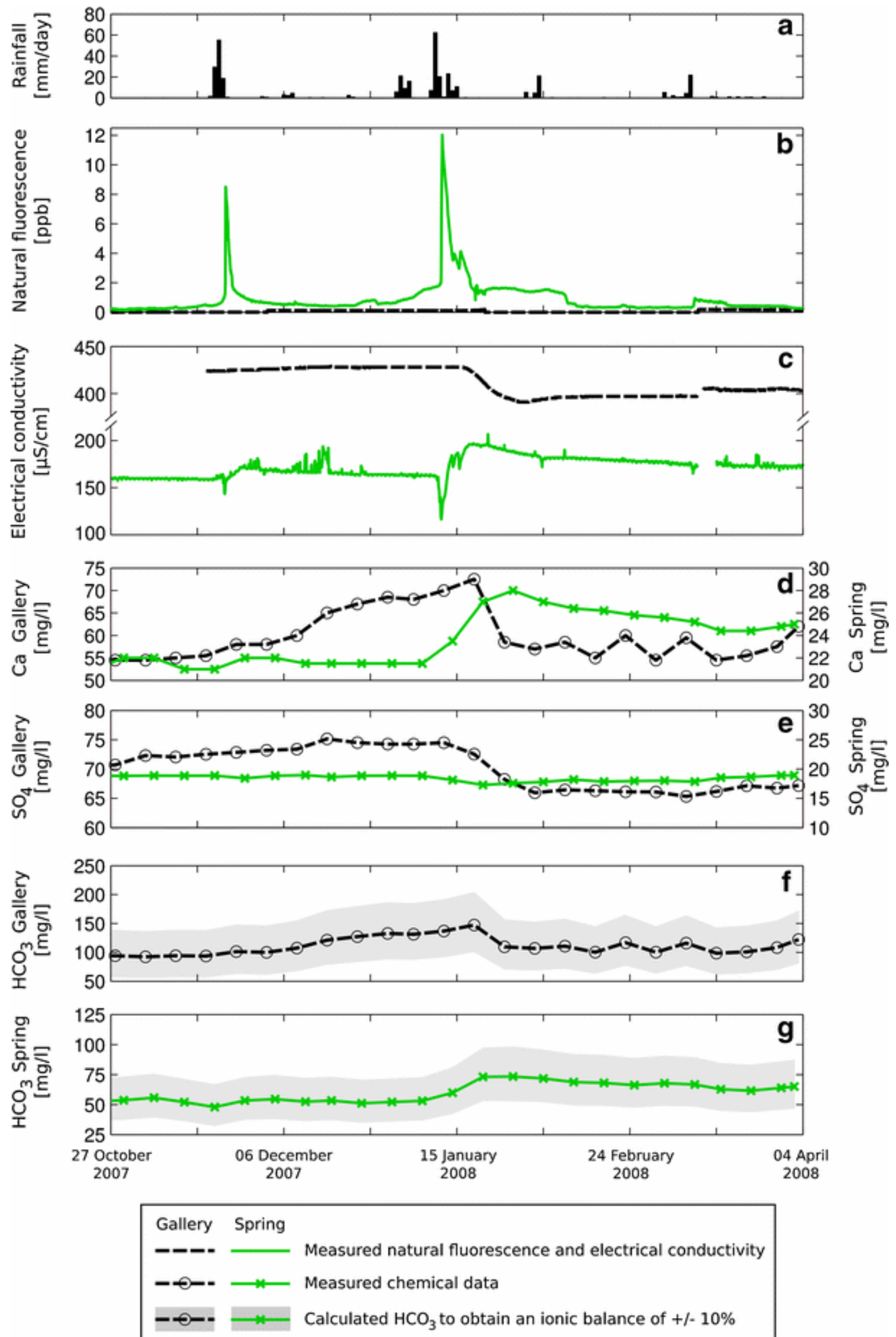

Fig. 2 Physical and chemical time series monitored in groundwater at the outlet of a fissure in the Gallery, and in stream water at the outlet of the Luicetta spring. From top to bottom: rainfall (a), natural fluorescence (b), electrical conductivity (c), $\mathrm{Ca}^{2+}(\mathbf{d}), \mathrm{SO}^{2-}(\mathbf{e}), \mathrm{HCO}_{3}^{-}(\mathbf{f}$ and $\mathbf{g})$ 


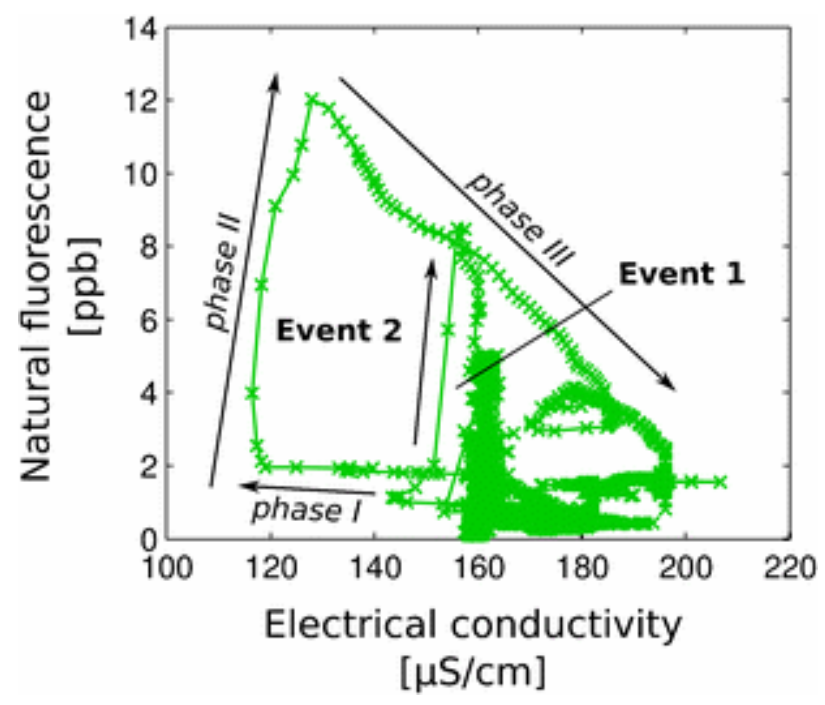

Fig. 3 Plot of natural fluorescence vs. electrical conductivity for stream water at the outlet of the Luicetta spring

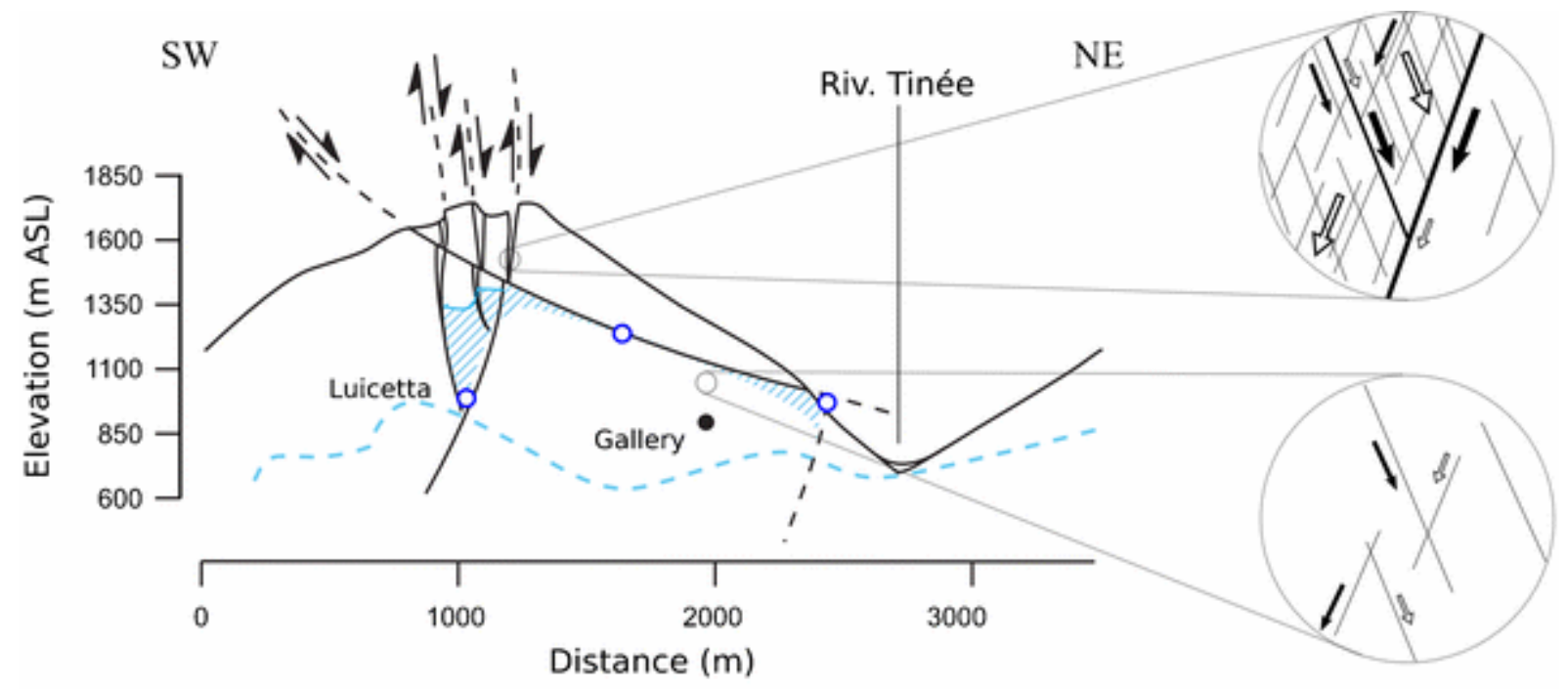

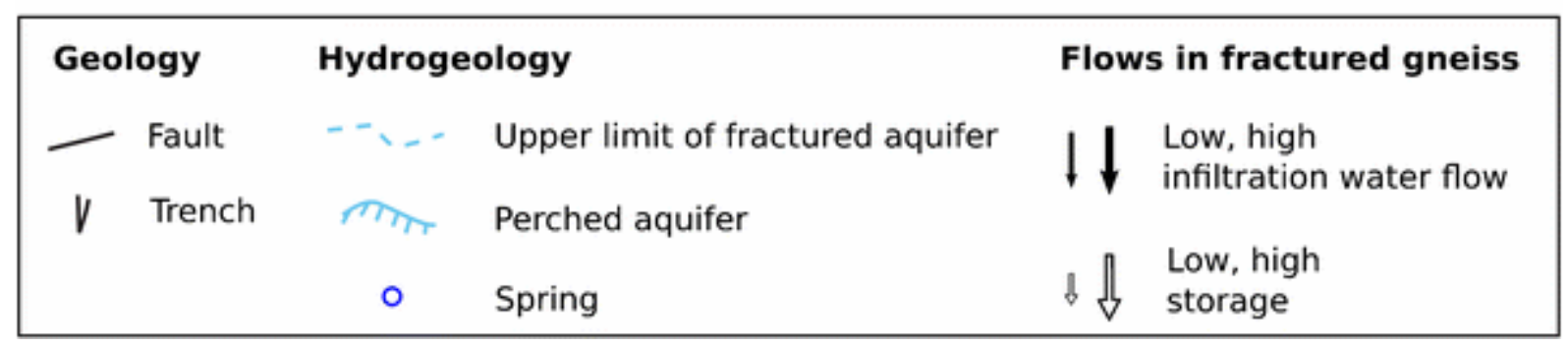

Fig. 4 Conceptual model of infiltration flows in the Valabres unstable rock 
Table 1 Temporal variability of major elements measured weekly from 22 October 2007 to 04 April 2008

\begin{tabular}{|l|l|l|l|l|l|l|l|l|l|}
\hline & $\mathbf{C a}^{2+}$ & $\mathbf{M g}^{2+}$ & $\mathbf{N a}^{+}$ & $\mathbf{K}^{+}$ & $\mathbf{F}^{-}$ & $\mathbf{C l}^{-}$ & $\mathbf{N O}_{3}$ & $\mathbf{S O}_{4}{ }^{2-}$ & $\mathbf{H C O}_{\mathbf{a}}{ }^{-}$ \\
\hline Img/l] & & & & & & & & \\
\hline Gallery & & & & & & & \\
\hline min & 53.50 & 3.20 & 4.40 & 0.93 & 0.01 & 4.95 & 2.47 & 65.33 & 92.23 \\
\hline mean & 59.70 & 3.45 & 4.69 & 1.03 & 0.08 & 5.87 & 3.80 & 70.18 & 110.41 \\
\hline max & 72.50 & 3.80 & 5.20 & 1.24 & 0.10 & 6.90 & 5.39 & 75.15 & 147.21 \\
\hline SD & 5.59 & 0.17 & 0.24 & 0.09 & 0.02 & 0.63 & 1.33 & 3.51 & 15.43 \\
\hline Spring & & & & & & & \\
\hline min & 21.00 & 2.40 & 2.20 & 0.77 & 0.02 & 4.01 & 0.00 & 17.28 & 47.95 \\
\hline mean & 23.67 & 2.75 & 2.60 & 0.81 & 0.03 & 5.06 & 2.06 & 18.46 & 60.03 \\
\hline max & 28.00 & 3.20 & 3.00 & 0.92 & 0.05 & 6.53 & 3.89 & 18.96 & 73.41 \\
\hline SD & 2.29 & 0.20 & 0.21 & 0.04 & 0.01 & 0.60 & 1.12 & 0.51 & 7.92 \\
\hline
\end{tabular}

${ }^{\mathrm{a}} \mathrm{HCO}_{3}{ }^{-}$calculated to obtain a null ionic balance 